\title{
СТАНОВЛЕНИЕ ИНСТИТУТА СЛЕДСТВЕННОГО СУДЬИ: НЕКОТОРЫЕ ОСОБЕННОСТИ КАЗАХСТАНСКОГО УГОЛОВНОГО ПРОЦЕССА
}

Аннотация: В данной статье анализируются некоторые положения проекта уголовно-процессуального кодекса Республики Казахстан, касающиеся создаваемого института следственного судьи в досудебном производстве. Опыт европейских государств, а также стран СНГ, использованный при разработке законопроекта, свидетельствует о важности расширения судебноконтрольных полномочий в стадии расследования уголовного дела в целях обеспечения судебной защиты прав и свобод лии, вовлеченных в уголовный прочесс. Проект нового УПК обсуждается в Парламенте страны и уже одобрен в первом чтении. Предполагаемая дата его введения в действие - 01 июля 2014 года. В работе используются историко-правовой и сравнительно-правовой методы на основе изучения положительного опыта зарубежных стран романо-германской правовой системы. Институт следственного судьи имеет давнюю историю и успешно функционирует в ряде цивилизованных стран. Для Республики Казахстан создание данной фигуры является новшеством, в связи с чем автором принимаются некоторые попытки освещения специфики его деятельности, а также мнения представителей юридической общественности относительно предлагаемого варианта законопроекта его разработчиком. Вносятся предложения по повышению правового статуса и безотлагательному расширению полномочий следственного судьи.

Ключевые слова: проект УПК РК, следственный судья, суд, судебный контроль, санкция, уголовное судопроизводство, реформа уголовного процесса, негласные следственные действия, полномочия, прокуратура.

DOI: 10.7256/1994-1471.2014.4.11134

$\mathrm{H}$ а протяжении XIX века во многих западноевропейских и азиатских государствах происходило широкомасштабное реформирование систем судоустройства и судопроизводства. С учетом зарубежного опыта, в особенности Франции, Александром II в рамках объявленной Судебной реформы были утверждены Судебные уставы от 20 ноября 1864 года, среди которых - Устав уголовного судопроизводства (УСС) ${ }^{1}$. Реформирование судоустройства привело к становлению судебной системы и на территории современного Казахстана, являвшегося к тому времени составной частью Российской империи, где до этого времени правосудие вершилось народными судами биев ${ }^{2}$.

Устав уголовного судопроизводства // http:// constitution.garant.ru; сайт конституции Российской Федерации: (дата обращения 22.02.2014).

Тукиев А. Нормы заочного уголовного судопроизводства в обычном праве казахов // Тураби. 2004. №4. C. $107-113$.
УСС предусматривал переход от инквизиционного к состязательному уголовному процессу, где предварительное следствие осуществлялось судебными следователями, переданными в подчинение от административной к судебной власти, образовывались суды присяжных, вводились такие демократические принципы, как гласность и публичность судопроизводства, презумпция невиновности, равноправие сторон, право на судебную защиту, независимость судов ${ }^{3}$.

Реформаторы XIX века понимали необходимость расширения и судебно-контрольных полномочий, в особенности, в стадии досудебного производства, в связи с чем в главе 12 раздела 2 УСС было закреплено право участников уголовного процесса до поступления дела в суд приносить жалобы на всякое действие следователя, нарушающее или стесняющее их права, непосредственно в окружной суд. Применение мер пресечения, таких как отдача под особый надзор полиции, взятие залога, домашний арест и

(c) Идиров Ерлан Илишевич

* Аспирант кафедры уголовно-процессуального права, Московский государственный юридический университет имени О.Е. Кутафина (МГЮА)

[travian.2014@mail.ru]

140800, Республика Казахстан, Павлодарская обл., Майский район, село Коктобе, ул. Сыздыкова, д. 1. 
взятие под стражу и других, предусмотренных ст. 416 УСС, также являлось прерогативой судебной власти, учитывая, что судебные следователи являлись ее представителями.

Многие фундаментальные положения УСС спустя полтора века сохранились в современных законодательных актах, регулирующих вопросы уголовного судопроизводства, ряда государств, в том числе стран СНГ. Все большее внимание стало уделяться вопросу расширения сферы судебного контроля в досудебном производстве по уголовным делам, целью которого является своевременная судебная защита прав и свобод лиц, вовлеченных в уголовный процесс.

Одним из действенных методов решения данного вопроса видится в создании новой (для постсоветских стран) процессуальной фигуры на уголовно-правовом поле - следственного судьи, призванного осуществлять весь комплекс судебно - контрольных полномочий на досудебной стадии и, что важно, отделенного от функций по расследованию дел.

Еще в советские годы д.ю.н. В.Коган задавался вопросом: «Почему бы не быть следственному судье?», объясняя необходимость его введения в уголовное судопроизводство многочисленными фактами нарушений законности в процессе расследования преступлений. Он утверждал, что «введение следственного судьи позволит защите пользоваться возможностями прокурора, следователя и органов дознания для сбора и проверки информации не посредством обращения к другой стороне, как это делается сейчас, а посредством обращения к следственному судье, указания которого будут обязательными для сторон» ${ }^{3}$.

Научные дискуссии по поводу введения данного института обретают новый характер в связи с проводимыми судебными реформами последнего времени и заявлениями высших должностных лиц. К примеру, председатель Конституционного Совета Российской Федерации В.Зорькин, выступая на Всероссийском съезде судей в декабре 2012 года, отметил о назревшей необходимости разработки и принятия законодательных решений о создании института следственных судей. По его мнению, это «... не только повысит эффективность судебного контроля в ходе расследования и объективность судебного разбирательства, но и поможет разорвать «обвинительную связку» между следствием и судом...» .

\footnotetext{
Коган В. Почему бы не быть следственному судье? // Советская юстиция. - М.: Юрид. лит., 1988, №7. - С. 26-27.
}

4 Из выступления председателя Конституционного Суда Российской Федерации В.Д. Зорькина на VIII Все-
В поддержку института следственного судьи выступают многие современные ученые, среди них доктора юридических наук Ковтун Н.Н., Колоколов Н.А., Муратова Н.Г., Гуськова А.П., Сулейменова Г.Ж. и многие другие. В то же время имеются и противники подобных новшеств в уголовном процессе. Так, профессор А.С. Барабаш, сомневаясь в оправданности «... параллельного существования судебного контроля и прокурорского надзора за предварительным следствием...» аргументированн утверждает, что вопрос об ограничении конституционных прав может решать не только суд, но и прокурор 5 .

Как известно, в мировой практике институт следственного судьи получил развитие еще при Наполеоне Бонапарте в связи с принятием Уголовного кодекса Франции в 1810 году, по которому такие судьи являлись, однако, следователями при суде, наделенными всеми полномочиями по самостоятельному ведению предварительного следствия. По аналогии с французской моделью должности судебных следователей в XIX веке появлялись и в ряде других западных стран, а также были предусмотрены в УСС Российской империи, где судебный следователь сам расследовал преступления.

В современном мире значимость следственного судьи видится именно как юрисдикционного судебного органа, не связанного с непосредственными функциями по расследованию дел. Заметная активность по внедрению данного института в уголовное судопроизводство своих стран наблюдается и на территории постсоветского пространства, с учетом своих особенностей. В прибалтийских государствах, Молдове и Украине судебно - контрольные функции на досудебной стадии осуществляют специализированные судьи, которым предоставлен широкий круг полномочий для реальной защиты конституционных прав и свобод граждан. В России и Киргизии, несмотря на отсутствие следственного судьи, пределы оперативного судебного контроля распространены на ряд негласных следственных действий, ограничивающих права граждан, проведение которых невозможно без разрешения суда.

Впервые должность следственного судьи на просторах СНГ введена в Украине в связи с принятием в 2012 году нового УПК, в котором определен круг его полномочий - это осущест-

российском съезде судей. Москва. 18 декабря 2012 года // Сайт Совета судей Российской Федерации: (дата обращения: 22.02.2014).

Барабаш А.С. Прокурор - следственный судья // Уголовная юстиция: связь времен. Избранные материалы международной научной конференции. Санкт-Петербург, 6-8 октября 2010 года. - М.: ЗАО «Актион-Медиа», 2012. - C. 6-12. 
вление судебного контроля за соблюдением прав, свобод и интересов лиц в уголовном производстве ${ }^{6}$.

Следственные судьи в Украине состоят в структуре судов первой и апелляционной инстанции общей юрисдикции и, в зависимости от этого, различаются порядком наделения соответствующими полномочиями и компетенцией. Так, если следственный судья в суде первой инстанции избирается собранием судей из состава судей этого суда, то в апелляционной инстанции следственного судью определяет председатель соответствующего суда. Причина неоднообразного подхода при назначении следственного судьи объясняется, видимо, разграничением круга их полномочий, поскольку лишь следственный судья уровня апелляционной инстанции наделен правом рассмотрения ходатайств органов уголовного преследования о проведении негласных следственных (розыскных) действий. Всеми остальными судебно-контрольными полномочиями на досудебной стадии обладают соответствующие следственные судьи первой инстанции.

Украинский законодатель наделил следственного судью достаточно широким объемом юрисдикционных полномочий в целях защиты прав и свобод личности путем установления судебного контроля за применением мер обеспечения уголовного судопроизводства, в том числе мер пресечения, судебного контроля за проведением негласных следственных (розыскных) действий и судебного контроля по рассмотрению жалоб на органы досудебного расследования или прокурора во время досудебного расследования.

Республика Казахстан, взяв курс на реформирование уголовного судопроизводства с учетом опыта вышеуказанных и других европейских стран, осознает важность расширения пределов судебного контроля в досудебном производстве. Об этом и других перспективах развития судебной системы говорится в Концепции правовой политики Pеспублики Казахстан на период с 2010 по 2020 годы ${ }^{7}$. В этих целях уже с 01 июля 2014 года предполагается принятие совершенно нового УПК Казахстана, предусматривающего наряду с другими новеллами, введение должности следственного судьи в уголовное судопроизводство. Законопроект в настоящее время об-

6 Уголовно-процессуальный Кодекс Украины // Голос Украины. 2012. 19 мая.

Указ Президента Республики Казахстан от 24 августа 2009 года № 858 «О Концепции правовой политики Республики Казахстан на период с 2010 по 2020 годы» // Казахстанская правда. 2009. 27 августа. суждается в стенах Парламента и уже одобрен в первом чтении ${ }^{8}$.

Президент страны Н.А. Назарбаев в своем выступлении на VI Съезде судей Республики Казахстан 20 ноября 2013 года выразил свою позицию по данному вопросу, отметив, что «введение института следственных судей повысит роль судов в контроле за досудебным производством, расширится круг санкционируемых судом следственных действий» ${ }^{9}$. По его поручению с 2014 года в Казахстане увеличивается количество судей на 450 единиц, то есть на 25\%. Таким образом, позиция главы государства не оставляет сомнений в том, что новая судейская фигура в ближайшее время займет свое достойное место в уголовном судопроизводстве страны.

На официальном сайте разработчика законопроекта - Генеральной прокуратуры Республики Казахстан представлен проект УПК по состоянию на 01 октября 2013 года для общественного обсуждения ${ }^{10}$. Предыдущие версии проекта подвергались неоднократной корректировке, однако, касательно компетенции следственного судьи, серьезных изменений не произошло.

Несмотря на заверения экс-председателя Верховного Суда Республики Казахстан Б.А.Бекназарова о том, что новый УПК Казахстана будет на 90\% похож на украинский кодекс $^{11}$, относительно создаваемого института следственного судьи анонсированный опыт Украины и других европейских стран, к сожалению, был перенят незначительно, как всегда, с учетом своих особенностей. Лишь во внешней их схожести убежден заслуженный юрист Украины, д.ю.н. Онищук Н.В., который доказывает, что УПК Украины предусматривает гораздо большее количество (примерно в 3 раза) полномочий следственного судьи, чем проект УПК Казахстана ${ }^{12}$. Это при том, что Украина не

8 Пострадавшим - гарантированную компенсацию // Юридическая газета. 2014. 7 февраля. С. - 4.

9 Из выступления Президента РК Н.А.Назарбаева на VI Съезде судей Республики Казахстан // Зангер. 2013. №11. C. 7.

10 Проект Уголовно-процессуального кодекса Республики Казахстан по состоянию на 1 октября 2013 года // http://prokuror.gov.kz; Официальный сайт Генеральной прокуратуры Республики Казахстан: (дата обращения: 22.02.2014).

11 Бекназаров Б.А. Новый УПК Казахстана почти на 90\% будет похож на украинский кодекс // Закон и Бизнес. 2013. 22-28 июня.

12 Онищук Н.В. Проект Уголовно-процессуального кодекса Республики Казахстан и Уголовно-процессуального кодекса Украины: схожесть и основные различия. Материалы международной экспертно-практической конференции. Астана. 15.11.2013. С. 13-17. 
является лидером по распространению судебного контроля на досудебной стадии уголовного процесса.

Действительно, по УПК Украины только с разрешения следственного судьи возможны отвод участников досудебного производства (следователей, прокуроров, представителей, защитников), применение всех мер пресечения, проведение следственных действий, таких как осмотр и обыск жилища, помещения и иного владения юридического лица, допрос свидетеля, потерпевшего на досудебной стадии, проведение 9 из 12 предусмотренных негласных следственных действий (аудио- и видеоконтроль лица, арест, осмотр и выемка корреспонденции, снятие информации, осмотр публично недоступных мест, жилища и иного владения лица, установление места расположения радиоэлектронного средства, слежка за лицом, местом, вещью, аудио-, видеоконтроль места, негласное получение образцов для сравнительного исследования). Конечно же, опыт Украины в данной сфере не является уникальным и безукоризненным и имеет свои недостатки, на которые, к примеру, обращает внимание Ковтун Н.Н. ${ }^{13}$, но украинский законодатель, создав впервые среди стран СНГ должность следственного судьи и наделив его реальными судебно-контрольными полномочиями на основе европейского опыта, показал свою принципиальную позицию относительно ключевого места и роли суда в досудебном судопроизводстве по уголовным делам, призванного защищать права и свободы человека.

К сожалению, на данном этапе в проекте УПК Казахстана не планируется распространение оперативного судебного контроля за производством следственных действий, ограничивающих конституционные права и свободы личности, как одного из главных юрисдикционных функций следственного судьи. Санкционирование всех негласных следственных действий (аудио, видеоконтроль лица и места, наблюдение, прослушивание и запись разговоров, снятие информации со всех устройств, контроль почтовых и иных отправлений, проникновение в жилое и иное помещение и другие) предполагается оставить за прокурором. Причем их проведение будет возможным даже по преступлениям, относящимся к категории небольшой тяжести (ч.4 ст. 232 проекта УПК РК). Такая позиция разработчиков законопроекта изначально вызывала наибольшее воз-

\footnotetext{
13 Ковтун Н.Н. Следственный судья Украины: анализ юрисдикционных и следственных функций в контексте российских процессуальных аналогов // Уголовное судопроизводство. №3/2013. С. 26-32.
}

мущение юридической общественности ${ }^{14}$. Оно и понятно, так как совершенно очевидно, что наделение прокуратуры, как стороны государственного обвинения в уголовном процессе, правом давать разрешение на проведение действий, связанных с ограничением конституционных прав и свобод, в отношении другой стороны - стороны защиты, не соответствует принципу состязательности и равноправия сторон обвинения и защиты. Г.Насыров убежден, что «отказ от расширения контрольного полномочия суда отбрасывает казахстанское судопроизводство в эпоху господства процессуального упрощенства и массового произвола, невинной жертвой которого легко может оказаться любой из нас» ${ }^{15}$. К месту отметить, практически во всех странах, опыт которых и использован при разработке проекта нового УПК Казахстана, проведение негласных следственных действий невозможно без судебного разрешения. Хотелось бы верить, что законодательным органом страны будет дана принципиальная оценка данному вопросу в ходе обсуждения законопроекта.

Другой важной проблемой рассматриваемого законопроекта, на наш взгляд, является предлагаемый порядок избрания/назначения следственного судьи и его оставление в составе суда общей юрисдикции. Правовой статус данного судьи имеет первостепенное значение при реформировании оперативного судебного контроля на досудебной стадии.

Так, согласно ч.1 ст. 56 проекта УПК РК, следственный судья (судьи) избирается собранием судей суда первой инстанции из числа судей этого суда, а при численности судей менее пяти назначается председателем этого суда. При необходимости замены следственного судьи он может быть переизбран или переназначен.

Как видим, предлагается два способа наделения полномочиями следственного судьи из числа действующих судей - путем избрания либо назначения в зависимости от штатной численности суда. Если учесть, что большинство районных судов в Казахстане не превышает пяти судей, можно утверждать, что выборность

14 См., например, Канафин Д. К. Совершенствование
правового статуса адвоката в свете разработки но-
вого уголовно-процессуального кодекса Республики
Казахстан // Юрист. 2012. № 12. С. 47-55.; Обращение
Республиканской коллегии адвокатов по вопросам ре-
формирования уголовного судопроизводства в рамках
разработки проекта уголовно-процессуального кодекса
Казахстана // Сайт республиканской коллегии адвока-
тов: htтр:// (дата обращения: 22.02.2014). 15 Насыров Г. Пересилят ли интересы общества ведомственные амбиции правоохранительных органов в споре за расширение контрольных полномочий суда // Тураби. 2005. № 2. С. 19-25. 
следственных судей будет проводиться лишь в городских многосоставных судах. На районном же уровне определение таких кандидатов ставится в зависимость от субъективного усмотрения председателя этого суда. При этом, следственный судья не освобождается от рассмотрения по существу уголовных дел, по которым он не участвовал в досудебном производстве, а также гражданских, административных и иных категорий дел, подсудных судам общей юрисдикции. Предлагаемый способ наделения полномочиями следственного судьи на одного из судей свидетельствует также о том, что данная должность не будет являться самостоятельной штатной единицей в судебной системе и постоянной для лица ее занимающего, а больше напоминать «дополнительную нагрузку для судьи». Очевидно, что новый институт следственного судьи в предложенном варианте (учитывая ограниченный круг предоставленных ему полномочий) не свидетельствует о кардинальном реформировании оперативного судебного контроля и будет незначительно отличаться от существующей модели судебного контроля на досудебной стадии уголовного судопроизводства.

Более реальным механизмом обеспечения независимости следственного судьи от внешнего (со стороны правоохранительных структур и региональной власти) и внутреннего (корпоративного) воздействия видится в его автономном функционировании от других судов, а также в организации его работы по экстерриториальному принципу, то есть вне пределов определенной административной территориальной единицы. Это могут быть межрайонные (окружные) суды по примеру функционирующих в Казахстане специализированных межрайонных экономических судов, судов по уголовным делам и по делам несовершеннолетних.

В необходимости дистанцирования следственного судьи от иных судей убеждены ряд ученых. Так, профессор Ковтун Н.Н. считает, что «автономно выделенный из структуры судов районного звена, организационно независимый от диктата вышестоящих судебных инстанций, изначально наделенный необходимыми процессуальными средствами для независимой и всесторонней проверки действий и решений следственных органов и прокурора, институт специализированных следственных судей может и должен стать необходимым звеном в системе сдержек и противовесов в механизме правового регулирования» ${ }^{16}$. Такого же мнения

16 Ковтун Н.Н. Следственный судья в уголовном судопроизводстве: за и против // Российская юстиция. - М.: Юрист, 2010, №9. С. 44. придерживается профессор Сулейменова Г.Ж., полагая «важным для обеспечения процессуальной и организационной независимости судьи, осуществляющего судебный контроль за расследованием, его дистанцирование от судей, рассматривающих дело по существу» ${ }^{17}$.

Функционирование автономных межрайонных следственных судей позволило бы им специализироваться исключительно на судебном контроле в досудебном производстве по уголовным делам и наиболее профессионально разрешать возникшие споры между участниками процесса, не отвлекаясь на рассмотрении иных категорий дел. Помимо обеспечения независимости, автономность позволила бы избежать необходимости образования таких должностей в каждом районном суде, учитывая их низкую загруженность по подобной категории дел, что существенно сократит расходование бюджетных средств как один из аргументов противников введения данного института. Избираемость следственных судей в случае их дистанцирования от других судов будет невозможной, так как судьи местных судов, по Конституции страны, назначаются Указом Президента и не ограничены в сроке пребывания в должности. Однако, учитывая особую специфику работы следственных судей и тесное взаимодействие с органами уголовного преследования, профилактикой слияния их интересов и иных негативных последствий вполне могло бы стать законодательное закрепление их ротации либо сменяемости по примеру ограничительного срока пребывания в должности председателя местного суда.

В целях пополнения рядов следственных судей наиболее квалифицированными кадрами предлагается предусмотреть в качестве требований к кандидатам на данные должности наличие стажа работы судьей по рассмотрению уголовных дел не менее 5 лет по аналогии с законодательным требованием 5-тилетнего судейского стажа для претендентов на должность судьи областного и приравненного к нему суда ${ }^{18}$. Данные требования позволили бы исключить случаи наделения полномочиями следственного судьи не только лиц, впервые назначенных на судейскую должность, но и действующих судей, ранее не имевших достаточную практику рассмотрения уголовных дел, поскольку от этого зависит качество опе-

\footnotetext{
17 Сулейменова Г. Ж. Заключение научно-правовой экспертизы Концепции проекта Уголовно-процессуального кодекса Республики Казахстан // Юрист. 2012. №12.

18 Конституционный Закон Республики Казахстан от 25 декабря 2000 года №132 «О судебной системе и статусе судей РК» // «Ведомости Парламента Республики Казахстан», 2000 г., № 23, ст. 410.
} 
ративного судебного контроля. Стимулом для достойных кандидатов было бы и закрепление статуса следственного судьи на уровне судей областной инстанции, что отразится и на размере оплаты их труда. Как отмечалось выше, в Украине судьи апелляционной инстанции также могут наделяться полномочиями следственного судьи. В Казахстане уже имеется подобный пример наделения судов первой инстанции статусом областного и приравненного к нему суда ${ }^{19}$.

Расширение судебного контроля и, как следствие, создание нового института следствен- ного судьи в уголовном процессе Республики Казахстан вызывает интерес всего общества и находит заслуженную поддержку, поскольку в правовом государстве именно суд как вершитель правосудия призван защищать права и свободы граждан на досудебной стадии уголовного судопроизводства. Остается надеяться, что законодательным органом страны в процессе обсуждения проекта нового УПК будет учтен положительный опыт зарубежных стран, а также мнение юридической общественности, по становлению важнейшего судебного института.

\section{Библиография}

1. Тукиев А. Нормы заочного уголовного судопроизводства в обычном праве казахов // Тураби. 2004. №4. С. 107-113.

2. Коган В. Почему бы не быть следственному судье? // Советская юстиция. - М.: Юрид. лит., 1988, №7. - C. 26-27.

3. Барабаш А.С. Прокурор - следственный судья // Уголовная юстиция: связь времен. Избранные материалы международной научной конференции. Санкт-Петербург, 6-8 октября 2010 года. - М.: ЗАО «Актион-Медиа», 2012. - С. 6-12.

4. Бекназаров Б.А. Новый УПК Казахстана почти на 90\% будет похож на украинский кодекс // Закон и Бизнес. 2013. 22-28 июня.

5. Онищук Н.В. Проект Уголовно-процессуального кодекса Республики Казахстан и Уголовнопроцессуального кодекса Украины: схожесть и основные различия. Материалы международной экспертно-практической конференции. Астана. 15.11.2013. С. 13-17.

6. Ковтун Н.Н. Следственный судья Украины: анализ юрисдикционных и следственных функций в контексте российских процессуальных аналогов // Уголовное судопроизводство. 2013. №3. С. 26-32.

7. Насыров Г. Пересилят ли интересы общества ведомственные амбиции правоохранительных органов в споре за расширение контрольных полномочий суда // Тураби. 2005. № 2. С. 19-25.

8. Ковтун Н.Н. Следственный судья в уголовном судопроизводстве: за и против // Российская юстиция. - М.: Юрист, 2010, №9. С - 44.

9. Канафин Д. К. Совершенствование правового статуса адвоката в свете разработки нового уголовно-процессуального кодекса Республики Казахстан // Юрист. 2012. № 12. С. 47-55.

10. Сулейменова Г. Ж. Заключение научно-правовой экспертизы Концепции проекта Уголовнопроцессуального кодекса Республики Казахстан // Юрист. 2012. №12.

11. Идиров Е.И. Следственный судья в проекте нового УПК Республики Казахстан // Вопросы права и политики. - 2013. - № 9. - C. 14-26. DOI: 10.7256/2305-9699.2013.9.9555.

12. Лазарева В.А. Уголовный процесс как способ защиты прав и свобод человека и гражданина (назначение уголовного судопроизводства) // LEX RUSSICA (РУССКИЙ ЗАКОН). - 2010. № 3. - С. 540-550.

13. Мельников В.Ю. Обеспечение прав и законных интересов граждан в ходе уголовного процесса // Актуальные проблемы российского права. - 2011. - № 3. - С. 210-218.

\section{References}

1. Tukiev A. Normy zaochnogo ugolovnogo sudoproizvodstva v obychnom prave kazakhov // Turabi. 2004. №4. S. 107-113.

2. Kogan V. Pochemu by ne byt' sledstvennomu sud'e? // Sovetskaya yustitsiya. - M.: Yurid. lit., 1988, №7. - S. 26-27.

\footnotetext{
19 Указом Президента Республики Казахстан от 17 августа 2006 года № 158 образован специализированный финансовый суда в городе Алматы, приравненный к областному суду.
} 
3. Barabash A.S. Prokuror - sledstvennyi sud'ya // Ugolovnaya yustitsiya: svyaz' vremen. Izbrannye materialy mezhdunarodnoi nauchnoi konferentsii. Sankt-Peterburg, 6-8 oktyabrya 2010 goda. M.: ZAO «Aktion-Media», 2012. - S. 6-12.

4. Beknazarov B.A. Novyi UPK Kazakhstana pochti na $90 \%$ budet pokhozh na ukrainskii kodeks // Zakon i Biznes. 2013. 22-28 iyunya.

5. Onishchuk N.V. Proekt Ugolovno-protsessual'nogo kodeksa Respubliki Kazakhstan i Ugolovnoprotsessual'nogo kodeksa Ukrainy: skhozhest' i osnovnye razlichiya. Materialy mezhdunarodnoi ekspertno-prakticheskoi konferentsii. Astana. 15.11.2013. S. 13-17.

6. Kovtun N.N. Sledstvennyi sud'ya Ukrainy: analiz yurisdiktsionnykh i sledstvennykh funktsii v kontekste rossiiskikh protsessual'nykh analogov // Ugolovnoe sudoproizvodstvo. 2013. №3. S. 26-32.

7. Nasyrov G. Peresilyat li interesy obshchestva vedomstvennye ambitsii pravookhranitel'nykh organov v spore za rasshirenie kontrol'nykh polnomochii suda // Turabi. 2005. № 2. S. 19-25.

8. Kovtun N.N. Sledstvennyi sud'ya v ugolovnom sudoproizvodstve: za i protiv // Rossiiskaya yustitsiya. - M.: Yurist, 2010, № 9. S - 44.

9. Kanafin D. K. Sovershenstvovanie pravovogo statusa advokata v svete razrabotki novogo ugolovnoprotsessual'nogo kodeksa Respubliki Kazakhstan // Yurist. 2012. № 12. S. 47-55.

10. Suleimenova G. Zh. Zaklyuchenie nauchno-pravovoi ekspertizy Kontseptsii proekta Ugolovnoprotsessual'nogo kodeksa Respubliki Kazakhstan // Yurist. 2012. №12.

11. Idirov E.I. Sledstvennyi sud'ya v proekte novogo UPK Respubliki Kazakhstan // Voprosy prava i politiki. - 2013. - № 9. - C. 14-26. DOI: 10.7256/2305-9699.2013.9.9555.

12. Lazareva V.A. Ugolovnyi protsess kak sposob zashchity prav i svobod cheloveka i grazhdanina (naznachenie ugolovnogo sudoproizvodstva) // LEX RUSSICA (RUSSKII ZAKON). - 2010. - № 3. C. 540-550.

13. Mel'nikov V.Yu. Obespechenie prav i zakonnykh interesov grazhdan v khode ugolovnogo protsessa // Aktual'nye problemy rossiiskogo prava. - 2011. - № 3. - C. 210-218.

Материал поступил в редакцию 23 февраля 20142. 